\title{
A RELAÇÃO ENTRE O RELEVO E O CLIMA COMO PROPOSIÇÃO DE CARACTERIZAÇÃO DA FISIOLOGIA DA PAISAGEM EM PERNAMBUCO, BRASIL
}

\author{
THE RELATIONSHIP BETWEEN RELIEF AND CLIMATE AS PROPOSITION OF CHARACTERIZATION OF \\ LANDSCAPE PHYSIOLOGY IN PERNAMBUCO, BRAZIL
}

\author{
Lucas Suassuna De Albuquerque Wanderley', Ranyére Silva Nóbrega 2, Ayobami Badiru \\ Moreira², Rômulo Simões Cézar Menezes²
}

1/nstituto Federal de Alagoas (IFAL), Penedo, AL, Brasil

¿Universidade Federal de Pernambuco (UFPE), Recife, PB, Brasi

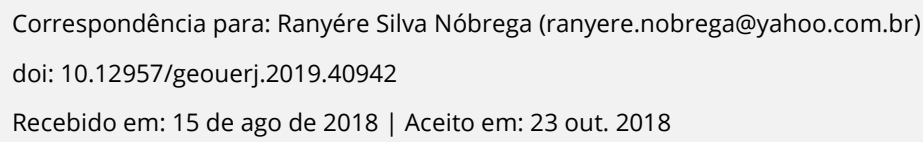

\section{RESUMO}

A expressiva diversidade ambiental e as variações topográficas ao longo do território do estado de Pernambuco (Brasil) sugerem que o padrão espacial das paisagens seja influenciado pela relação entre a dinâmica atmosférica e o relevo. Com objetivo de investigar a influência dessa relação sobre a distribuição espacial das paisagens foram executadas cinco etapas metodológicas: 1) classificação climática com base no índice de aridez, 2) elaboração de mapas de altitude, climático e de vegetação para o estado de Pernambuco, 3) delimitação de perfis a partir dos mapas climáticos e de altitude, 4) Análise de regressão linear entre os dados inseridos nos perfis e 5) elaboração de perfis paisagísticos com base nos dados de altitude, clima e vegetação. Os resultados demonstraram que a relação entre a distribuição espacial dos climas e os dados de altitude não ocorre de maneira linear em todos os perfis. O modelo de regressão linear apresentou maior previsibilidade para os perfis localizados nas mesorregiões do Sertão e do São Francisco. No Agreste a baixa previsibilidade linear foi relacionada à existência de relevo mais complexo, já na Região Metropolitana do Recife e Zona da Mata, a dinâmica dos sistemas atmosféricos atuantes favorece um aumento da aridez com o distanciamento do oceano. Pode-se, portanto, concluir que há uma forte relação entre o relevo e a distribuição espacial das paisagens na maior parte do estado de Pernambuco, principalmente na mesorregião do Sertão.

Palavras-chave: clima. índice de aridez. relevo. paisagens. Pernambuco.

\begin{abstract}
The expressive environmental diversity and topographical variations throughout the state of Pernambuco (Brazil) territory suggest that its landscape spatial pattern is influenced by the relation between atmospheric dynamics and relief features. In order to investigate the weight of this relation on the landscapes spatial distribution, five methodological steps were performed: 1) climatic classification based on aridity index; 2) altitude, climate and vegetation mapping for the state of Pernambuco; 3) delimitation of profiles from climatic and altitude maps; 4) Linear regression analysis on profiles data; and 5) Elaboration of landscaping profiles based on altitude, climate and vegetation data. Results demonstrated that the comparison between spatial distribution and altitude data do not occur linearly in all profiles. The linear regression model shows a better predictability for Sertão and São Francisco mesoregions profiles. The low linear predictability shown in Agreste mesoregion was related to the existence of a more complex relief, and in the Metropolitan Region of Recife and Zona da Mata microregions, the atmospheric dynamics systems favored an increase of aridity while distancing from the coast. It can therefore be concluded that there is a strong relation between relief and the spatial distribution of landscapes in most of the state of Pernambuco, especially in the Sertão mesoregion.
\end{abstract}

Keywords: climate. aridity index. relief. landscape. Pernambuco. 


\section{INTRODUÇÃO}

A interação do relevo com os elementos atmosféricos possui influência sobre a disposição espacial dos tipos climáticos e sobre a dinâmica das paisagens. Oliveira e Galvani (2015) destacam que o relevo pode influenciar a dinâmica climática a partir de quatro características principais: a posição, orientação e forma das vertentes, declividade e a altitude. A depender do arranjo espacial desses fatores, eles podem atuar de maneira a aumentar ou reduzir a disponibilidade hídrica ambiental, o que implicará em modificações fisiográficas ao longo de um transecto que perpasse áreas próximas com patamares distintos de relevo.

Com o avanço da tecnologia para obtenção de informações a respeito do tempo e clima, têm-se constatado, de maneira mais clara, que as terras elevadas possuem influência significativa sobre os sistemas convectivos atmosféricos, alterando a distribuição espacial das chuvas (MEDINA et al., 2010). Há três mecanismos principais descritos para a formação ou intensificação de chuvas em decorrência de barreiras orográficas: (i) a autoconversão é a ascensão forçada, pelo relevo, de parcelas de ar úmido que se resfriam e formam nuvens e chuva, (ii) a semeadura de nuvens mais baixas por nuvens mais altas, pode intensificar a precipitação na área do relevo proeminente e (iii) a convecção disparada, resultante do aquecimento diferencial das vertentes, pode fornecer energia à parcela de ar sobrejacente e gerar condição de instabilidade atmosférica local (SMITH, 1979).

Estes processos de gênese orográfica das chuvas estão associados às vertentes orientadas de maneira a barrar as correntes de ar, chamadas de encostas a barlavento. Por outro lado, as encostas de orientação oposta (sotavento) tendem a favorecer um movimento subsidente do ar atmosférico, gerando estabilidade e aquecimento por compressão sobre a superfície. Por esta razão, as áreas mais baixas do relevo, posicionadas a sotavento, tendem a receber menos precipitação, dando origem ao efeito da sombra de chuva (SILER et al., 2013).

Em estudo realizado nas paisagens áridas e semiáridas das Montanhas Qilian Shan, no nordeste do platô Tibetano, Geng et al. (2017) concluíram que a distribuição espacial da precipitação é bem explicada pela altitude, a topografia do relevo, porém, não apresenta relação linear significativa com a chuva no local investigado. Os autores atribuíram a fraca relação da distribuição da chuva com a 
topografia do relevo à baixa umidade do ar predominante na área de estudo, que seria capaz de elevar o nível de convecção livre nas vertentes do interior do platô. Para alcançar esses resultados, foram elaborados mapas de interpolação de dados pluviométricos, utilizado modelo digital de elevação, perfis de precipitação e topografia do terreno e foram aplicadas análises de regressão.

Na Austrália, Johnson et al. (2016) avaliaram o impacto da topografia sobre a distribuição espacial de eventos extremos de chuva. Foi constatado que em áreas de relevo não tão acentuado, correspondentes a maior parte do território australiano, a precipitação extrema possui relação espacial com a elevação, mas nas áreas de relevo proeminente a correlação não é tão evidente, em virtude da maior complexidade na circulação atmosférica gerada por relevos montanhosos.

A investigação da relação entre a precipitação e o relevo foi elaborada através de um perfil longitudinal por Oliveira e Galvani (2015) no sudeste brasileiro. Esses autores verificaram que as escarpas a barlavento da Serra do Mar e da Mantiqueira possuem mais alta pluviosidade do que áreas localizadas no setor a sotavento. De maneira similar, a instalação de pluviômetros em vertentes de orientações opostas, em Ilhabela no estado de São Paulo, demonstrou uma intensificação das chuvas a partir dos $600 \mathrm{~m}$ de altitude na vertente a barlavento, que apresentou volume pluviométrico $20 \%$ superior à vertente sotavento (MILANESI e GALVANI, 2011).

No Nordeste Brasileiro, Pereira (2013) demonstrou que no estado de Alagoas existe uma tendência de diminuição dos volumes pluviométricos em direção ao interior, com concentração de maiores valores médios de chuvas no litoral e nas cabeceiras de drenagem. Na microrregião do Sertão Central do estado de Pernambuco, Souza et al. (2015) verificou a existência de correlação entre a precipitação e a altitude, constatando a ocorrência de maiores índices de chuvas nas áreas mais elevadas e menores índices sobre a Depressão Sertaneja. No entanto, esses autores chamam a atenção para o fato de que essa relação não ocorre de maneira linear, e atribuem esse fato à irregularidade da topografia e atuação de diferentes mecanismos atmosféricos formadores de chuva.

Constata-se que a maioria dos estudos que investigam a influência do relevo sobre a dinâmica climática atêm-se às diferenças de pluviosidade das encostas a barlavento e sotavento. Porém, em ambientes 
tropicais com transições abruptas entre tipos climáticos (úmido-semiárido), a evapotranspiração assume um papel importante entre os elementos do clima, tendo em vista que ambientes a sotavento de áreas elevadas tendem a apresentar maior aquecimento superficial por compressão adiabática, enquanto áreas elevadas ou encostas expostas a ventos úmidos possuem temperaturas médias mais amenas.

Reboita et al. (2016) relacionaram a gênese do clima semiárido brasileiro aos movimentos atmosféricos subsidentes das células de Hadley e Walker. Os dados utilizados para a análise dos autores dificultaram relacionar os fatores geográficos e os elementos climáticos como parâmetros para a formação do semiárido nordestino, por exemplo. Outros autores, em trabalhos pretéritos, em um período sem tantos dados oriundos de instrumentos modernos, já levantavam que as condições geoambientais do Nordeste, e no caso deste trabalho aqui desenvolvido, em Pernambuco têm relação direta com as unidades da paisagem (para mais informações e referências ver Nogueira de Souza et al., 1992).

A influência do relevo ocorre quando o escoamento das vertentes a sotavento se acopla aos movimentos descendentes das células de circulação atmosféricas, o que aumenta as temperaturas médias e diminui a umidade relativa na baixa troposfera.

Assim, o Índice de Aridez (IA) (UNESCO, 1992), que representa uma razão entre precipitação e evapotranspiração potencial, pode ser utilizado como parâmetro de classificação climática (MATALLO JÚNIOR, 2003). Para investigar a influência do relevo sobre a distribuição dos climas, a utilização desse índice torna-se, portanto, mais adequada, pois as distinções entre os grupos paisagísticos poderão ser delimitadas mais facilmente a partir dos limites climáticos.

No contexto da circulação e dinâmica atmosférica, é importante considerar que os centros de ação climáticos atuantes sobre o Nordeste do Brasil em associação com os fatores geográficos locais, especialmente o relevo, são importantes aspectos da dinâmica e distribuição espacial das paisagens. Essa constatação pode ser observada em áreas como o estado de Pernambuco, onde há ocorrência de pelo menos três tipos mesoclimáticos associados a ambientes úmidos, subúmidos e semiáridos. 
Os estudos das influências entre o relevo e o clima podem indicar a distribuição dos recursos ambientais e, por essa razão, podem funcionar como ferramentas de gestão (SILER et al., 2013). Por esta razão, o presente estudo se propõe a investigar a relação entre o relevo e os tipos climáticos no estado de Pernambuco, Brasil, como base para uma caracterização paisagística.

\section{Materiais e métodos}

\section{Localização da área de estudo}

O estudo foi realizado no estado de Pernambuco a partir do delineamento de nove perfis, apresentados em vermelho na Figura 1, distribuídos entre as cinco mesorregiões. Os perfis 1 e 2 estão localizados na Região Metropolitana do Recife e Zona da Mata, os perfis 3,4 e 5 estão inseridos no Agreste e os perfis 6,7, 8 e 9 no São Francisco e no Sertão do estado.

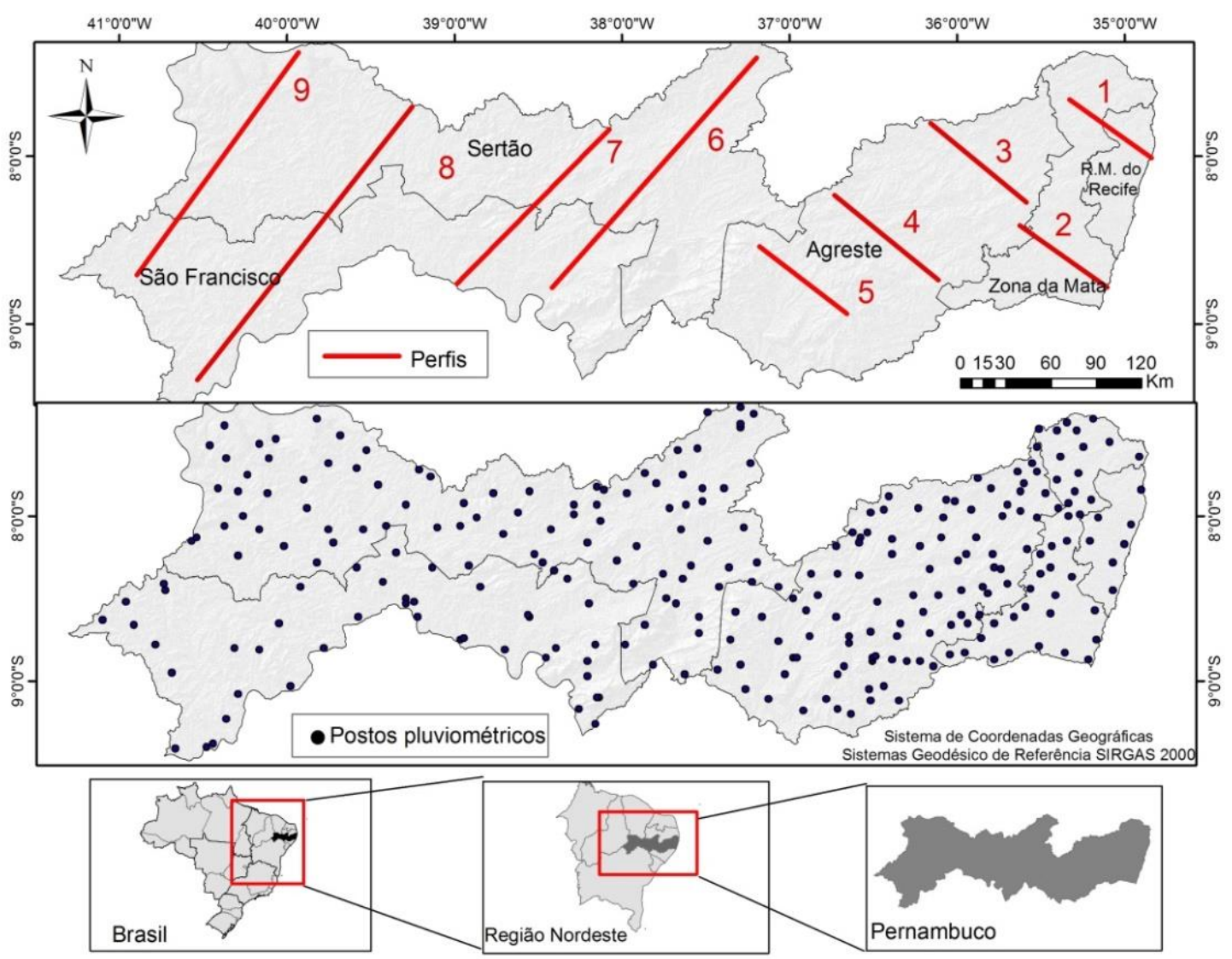

Figura 1. Localização dos perfis e dos postos pluviométricos no estado de Pernambuco, Brasil. Organizado pelos autores. Fonte: organizado pelos autores 


\section{Materiais e Procedimentos metodológicos}

A primeira etapa metodológica consistiu na elaboração de uma classificação climática para o estado de Pernambuco. Para esse propósito foi utilizado o índice de aridez (Matallo Junior, 2003), obtido pela razão entre a precipitação e a evapotranspiração potencial. Os intervalos de índice de aridez correspondentes aos respectivos tipos climáticos estão apresentados na Tabela 01 .

\begin{tabular}{ll}
\hline Classes climáticas & Índice de aridez \\
\hline hiperárido & $<0,05$ \\
árido & $0,05<0,2$ \\
semiárido severo & $0,21<0,3$ \\
semiárido & $0,31<0,5$ \\
subúmido seco & $0,51<0,65$ \\
subúmido úmido & $0,65<0,99$ \\
\hline
\end{tabular}

Tabela 1. Classes climáticas de acordo com o índice de aridez Fonte: Adaptado de Matallo Junior, 2003.

Os dados de precipitação foram adquiridos na Agência Pernambucana de Águas e Clima (APAC). As falhas nas séries de precipitação foram preenchidas com dados do Windows precipitation software (Winpreci) (SILVA, 2015). Esse software fornece dados históricos mensais (1950-2012), obtidos por interpolação da precipitação das estações do Instituto de Tecnologia de Pernambuco (ITEP) e Instituto Nacional de Meteorologia (INMET). Os dados de temperatura foram estimados pelo software EstimaT, desenvolvido na unidade de ciências atmosféricas da Universidade Federal de Campina Grande (SILVA, et al., 2006). Os valores médios de evapotranspiração potencial anual foram obtidos através da metodologia de Thornthwaite e Matter (1955). A espacialização dos 230 postos pluviométricos, que também correspondem aos pontos de estimativas de temperatura, está apresentada na Figura 1.

Os dados de índice de aridez foram interpolados no software Arcgis 10.3 pela função geoestatística Inverse Distance Weighting (IDW). Para escolha do método de interpolação foi aplicado o teste de validação cruzada entre o IDW e a Krigagem, e foi selecionado aquele que apresentou menor valor da raiz do erro médio quadrado para a escala local dos perfis elaborados nos mapas. Em seguida foi 
elaborado um mapa hipsométrico para o estado de Pernambuco a partir dos dados do modelo digital do terreno tratado pelo Projeto Topodata (BRASIL, 2008).

O índice de aridez e os dados de altitude foram utilizados para elaboração de perfis comparativos entre os dados desses dois produtos. Os perfis apresentados na Figura 1 foram gerados, assim como os mapas, no software Arcgis 10.3. O objetivo desse procedimento foi avaliar comparativamente as relações existentes entre as variações topográficas e climáticas ao longo dos perfis. Os mesmos foram projetados sobre as camadas de IA e altitude em duas direções, em consonância com a direção dos ventos associada os sistemas sinóticos produtores de chuvas.

Para as mesorregiões da Zona da Mata e Agreste de Pernambuco, o período de chuvas ocorre entre março e julho, e é decorrente principalmente da propagação de Distúrbios Ondulatórios de Leste (DOL) os quais avançam em direção ao continente no sentido SE-NO, seguindo a direção predominante dos alísios. No interior do estado, os sistemas convectivos provenientes da Zona de Convergência Intertropical (ZCIT) possuem propagação predominante na direção NE-SO, entre os meses de janeiro a maio (MOLION E BERNARDO, 2002). Por esta razão, os perfis foram orientados de SE-NO na Zona da Mata e Agreste e de NE-SO no Sertão.

A partir de então, os dados topográficos e o IA, ao longo dos perfis, foram relacionados a partir de uma regressão linear, a fim de avaliar o grau de correlação existente ente a distribuição espacial dos tipos climáticos e a topografia do relevo.

Foram elaborados gráficos dos perfis topográficos associados com as possíveis paisagens fitoclimáticas. Para isso, os tipos climáticos foram relacionados a combinações possíveis de grupos vegetacionais pretéritos (pois muitas destas composições florísticas já foram alteradas pela ação humana) (Quadro 1) com base na classificação do projeto RADAMBRASIL. 


\begin{tabular}{|cc|}
\hline Grupos climáticos & Tipo climático \\
\hline S1 & Semiárido severo \\
S2 & Semiárido \\
S3 & Subúmido seco \\
S4 & Subúmido úmido \\
U & Úmido \\
\hline Grupos vegetacionais & Tipos vegetacionais \\
C & Caatinga \\
Ca & Caatinga Arborizada \\
Fe & Caatinga Arbustiva \\
Fo & Floresta Estacional Semidecidual \\
\hline
\end{tabular}

Quadro 1. Classes climáticas e de vegetação utilizadas nos perfis paisagísticos Fonte: organizado pelos autores.

A Figura 2 é apresenta a cobertura vegetal primitiva do estado de Pernambuco, com a localização dos perfis delineados.

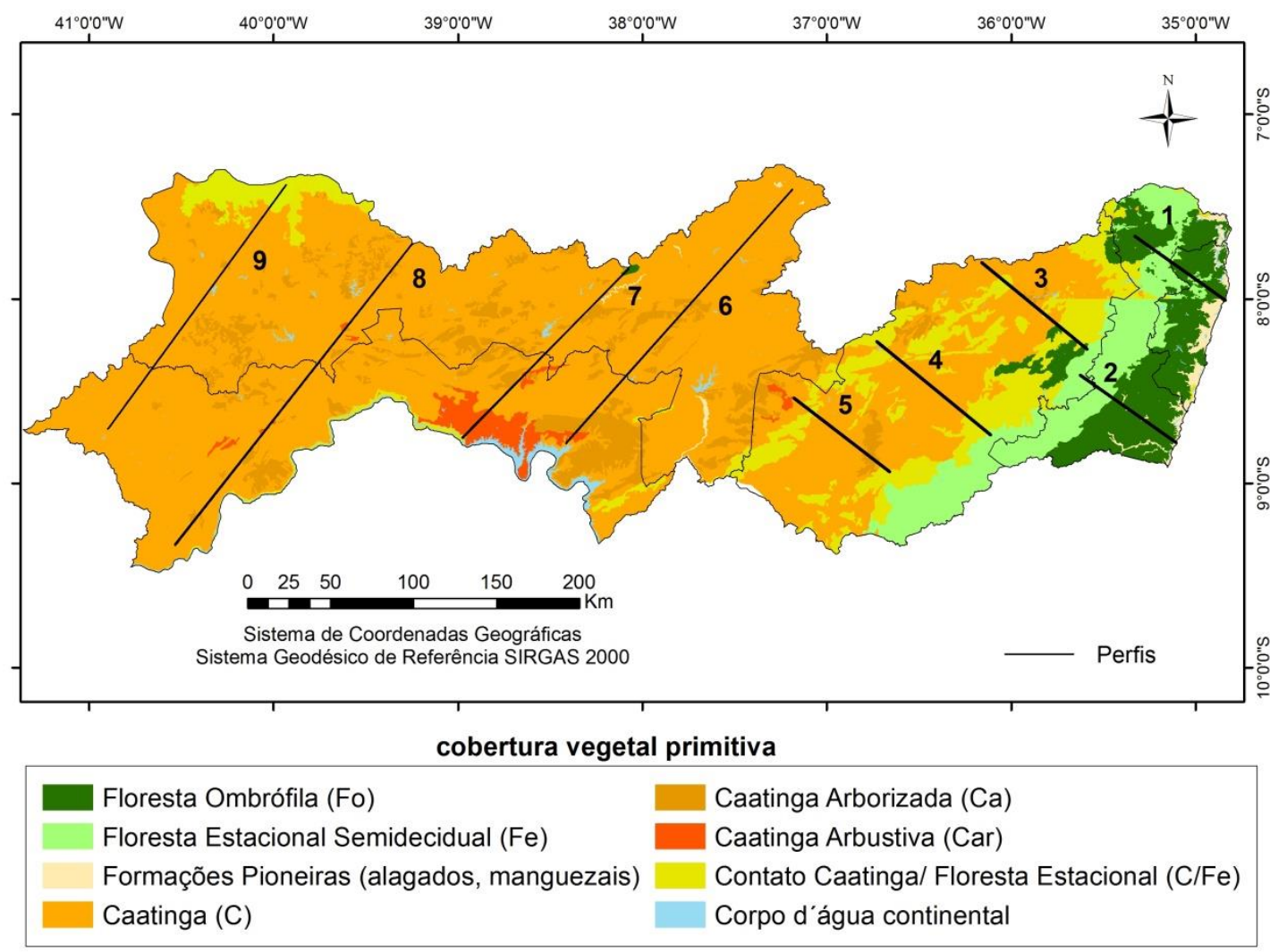

Figura 2. cobertura vegetal primitiva do estado de Pernambuco.Fonte: organizado pelos autores. 
Observa-se uma predominância de vegetação xerófila no interior do estado e florestas ombrófilas nas proximidades do litoral. Essa distribuição espacial da vegetação reflete o aumento da aridez à medida que a distância em relação ao oceano se torna maior.

\section{Resultados e Discussão}

\section{Análise dos perfis}

A análise dos perfis 1 e 2, apresentados na Figura 3(a) e (b), sugere que a relação entre o IA e a topografia seja inversamente proporcional, pois a medida que há um aumento da altitude no perfil topográfico, do litoral até os piemontes do Planalto da Borborema, ocorre um decréscimo do IA. Esses perfis apontam que há uma tendência de diminuição do índice de aridez até aproximadamente $65 \mathrm{Km}$ de distância em relação ao litoral, em um transecto orientado de SE paras NO. A maior disponibilidade de umidade na costa pode ser explicada pela atuação dos ventos alísios úmidos, atuação das brisas e dos DOLs (Molion e Bernardo, 2002) com maior energia sobre essas áreas.
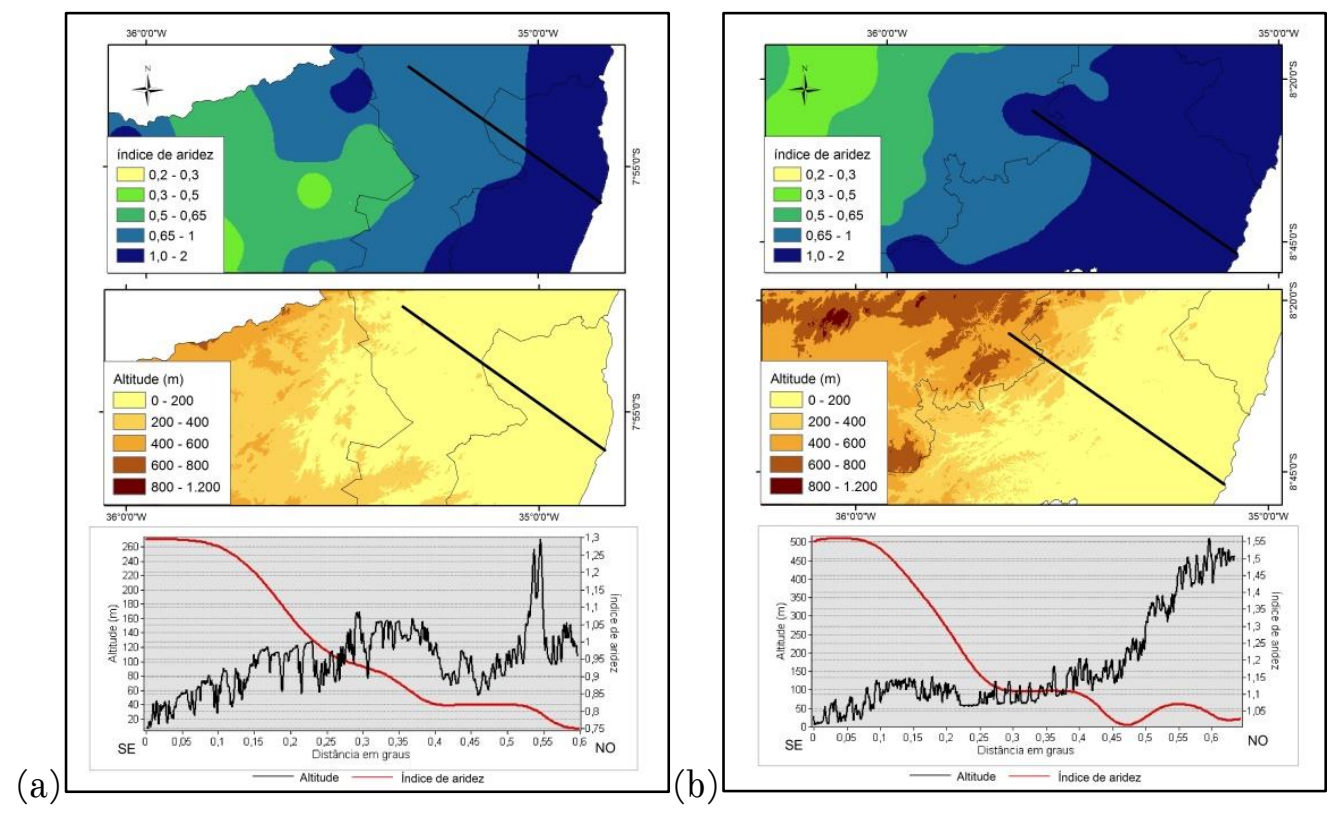

Figura 3. perfis 1(a) e 2(b) com dados relativos a altitude e ao índice de aridez (1960-2016). Fonte: organizado pelos autores.

Constatou-se que a partir da cota de 600m, nas escarpas orientais do Planalto da Borborema, ocorre uma tendência de inversão da relação entre o IA e a topografia em relação à tendência observada nos perfis da Zona da Mata. Nos perfis 3, 4 e 5, apresentados na Figura 4, orientados de SE para NO, 
observou-se que no interior do planalto os climas subúmidos úmidos ou até úmidos tendem a se localizar nas encostas a barlavento ou nos picos do relevo, demonstrando um maior controle topográfico sobre os elementos climáticos.

O perfil 3 possui $81 \mathrm{~km}$ de extensão e acentuada variação do IA e da altitude, as cotas de altitude variam entre 294 a 947 metros e os valores de IA entre 0,39 e 1,21. Há uma predominância ao longo de perfil de climas subúmidos, estando os climas semiáridos e úmidos com distribuição mais restrita. Os valores máximos de IA coincidem com os valores mais elevados de altitude, localizados no último terço do perfil, na área do brejo de Taquaritinga.

No perfil 4, que apresenta $88 \mathrm{Km}$ de extensão, os valores do IA indicaram a ocorrência de climas subúmidos úmidos e subúmidos secos, com predominância do segundo tipo. De 0 a 0,15 graus, até a cota de $600 \mathrm{~m}$, do perfil ocorre clima subúmido úmido, em escarpa a sotavento. Entre 0,15 e o 0,65 graus do perfil o relevo se apresenta como uma rampa suave com altitudes entre 600 e 700 m e há ocorrência de clima subúmido seco. Entre 0,75 e o 0,80 do perfil há um gradiente topográfico de 200 m, com ocorrência de clima subúmido úmido desde o quilômetro 0,65 (cota altimétrica de 700 m) por efeito da encosta a barlavento.

Entre os perfis apresentados na Mesorregião do Agreste de Pernambuco, o perfil 5 é aquele que mostra uma maior relação da topografia com a distribuição espacial do IA. O transecto de $73 \mathrm{Km}$ é marcado por uma depressão central semiárida e serras nos extremos do perfil onde há ocorrência de climas subúmido e úmido. Neste perfil, os primeiros 0,15 graus são marcados pela ocorrência de clima Subúmido úmido, e uma variação de altitude de 900 a $625 \mathrm{~m}$ em escarpa a sotavento. Na mesma encosta ente 0,15 e 0,2 graus predomina o clima subúmido seco até a cota topográfica de $500 \mathrm{~m}$. A área central do perfil (0,2 - 0,45 graus) é domínio de clima semiárido com altitudes iguais ou inferiores a $500 \mathrm{~m}$. A partir de 0,45 tem início uma escarpa com desnível abrupto de $300 \mathrm{~m}$, com climas subúmidos nas escarpas e úmido no topo da serra localizada ente 0,55 e 0,65 graus. 

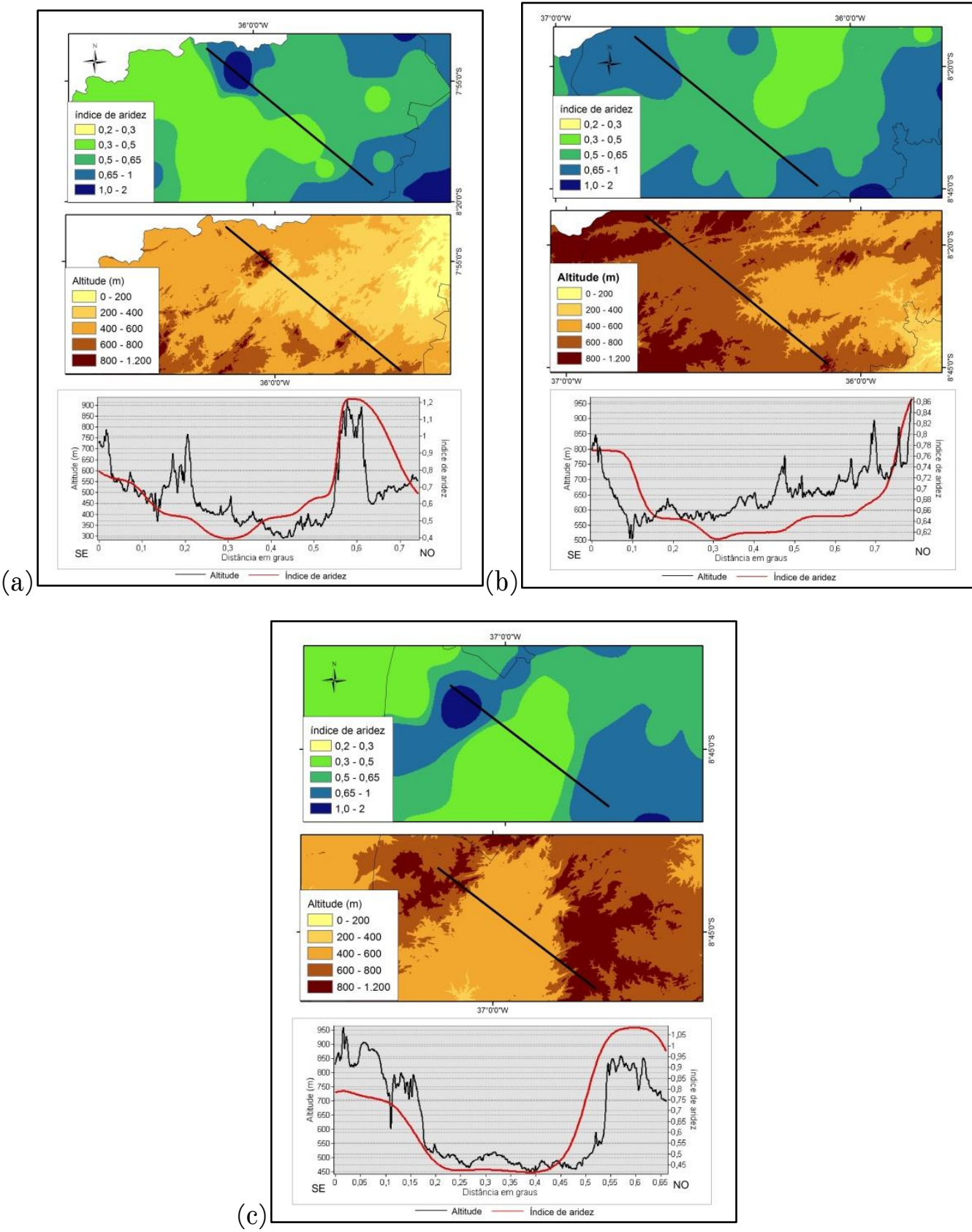

Figura 4. perfis 3(a), 4(b) e 5 (c) com dados relativos a altitude e ao índice de aridez (1960-2016). Fonte: organizado pelos autores

Os perfis 6, 7, 8 e 9 apresentados na Figura 5, estão localizados nas mesorregiões do Sertão e do São Francisco e foram orientados de NE-SO com objetivo de seguir o sentido de deslocamentos dos pulsos da ZCIT entre os meses de janeiro a maio. 0 perfil 6 possui extensão de $200 \mathrm{Km}$, com altitudes variando entre 320 a $700 \mathrm{~m}$. Neste perfil, de 0 a 1,0 grau predomina o clima subúmido seco, estando os maiores valores de IA situados entre 0,6 e 0,8 graus de distância em consonância com as áreas mais elevadas do relevo. Entre 1,0 e 2,0 graus o relevo se apresenta com uma rampa com declividade negativa. 0 clima semiárido ocorre a sotavento a partir da cota de 600 m e o clima semiárido severo 
$(\mathrm{IA}<0,3)$ a partir dos $400 \mathrm{~m}$, portando o grau de aridez aumenta a medida que a cotas topográficas diminuem.

No perfil 7 (com extensão de $140 \mathrm{Km}$ ), a correspondência entre a variação topográfica e o IA é ainda mais evidente. Nas áreas com altitudes superiores a 1000 m, no maciço da Baixa Verde, há ocorrência de clima úmido entre a origem do transecto e 0,5 graus de distância. A medida que as cotas do relevo tornam-se menores em direção a Depressão Sertaneja o IA diminui, indicando a presença do clima semiárido a partir de $550 \mathrm{~m}$ de altitude na escarpa a sotavento. Entre 0,1 e 1,0 graus de distância, em relação à origem do perfil, ocorre o clima semiárido, em cotas altimétricas que variam de 550 a $400 \mathrm{~m}$. A partir de 1,0 até final do transecto há incidência do clima semiárido severo em cotas de altitude de 400 a $300 \mathrm{~m}$.

Nos perfis 8 e 9 o comportamento do IA em relação a topografia do terreno ocorre de maneira semelhante à apresentada nos dois transectos anteriores, com aumento do índice de aridez em direção às terras mais baixas da Depressão Sertaneja. No transecto 8, que possui 224,6 Km de extensão, os valores de altitude tem variações entre $600 \mathrm{~m}$ e $360 \mathrm{~m}$, e ocorre clima semiárido ao longo de todo o perfil, com pequenas variação dos valores de IA que foram atribuídos a presença de relevos residuais. O clima semiárido severo ocorre a partir dos 380 m de altitude no último terço do percurso. 0 perfil 9 (com $180 \mathrm{Km}$ de extensão) corresponde a uma transição paisagística entre os patamares elevados da Chapada do Araripe com altitude que alcança os 900 m até o nível da Depressão Sertaneja entre 550 e $450 \mathrm{~m}$. Foi observada a presença do clima subúmido úmido, restrito ao topo da chapada, subúmido seco na escarpa abrupta a sotavento e semiárido a partir da cota topográfica de $550 \mathrm{~m}$. Também foram observadas a presença de serras secas a sotavento da Chapada do Araripe entre 0,9 e 1,1 graus de distância, com cotas altimétricas que alcançam 700 m sob o domínio do clima semiárido. 
(a)
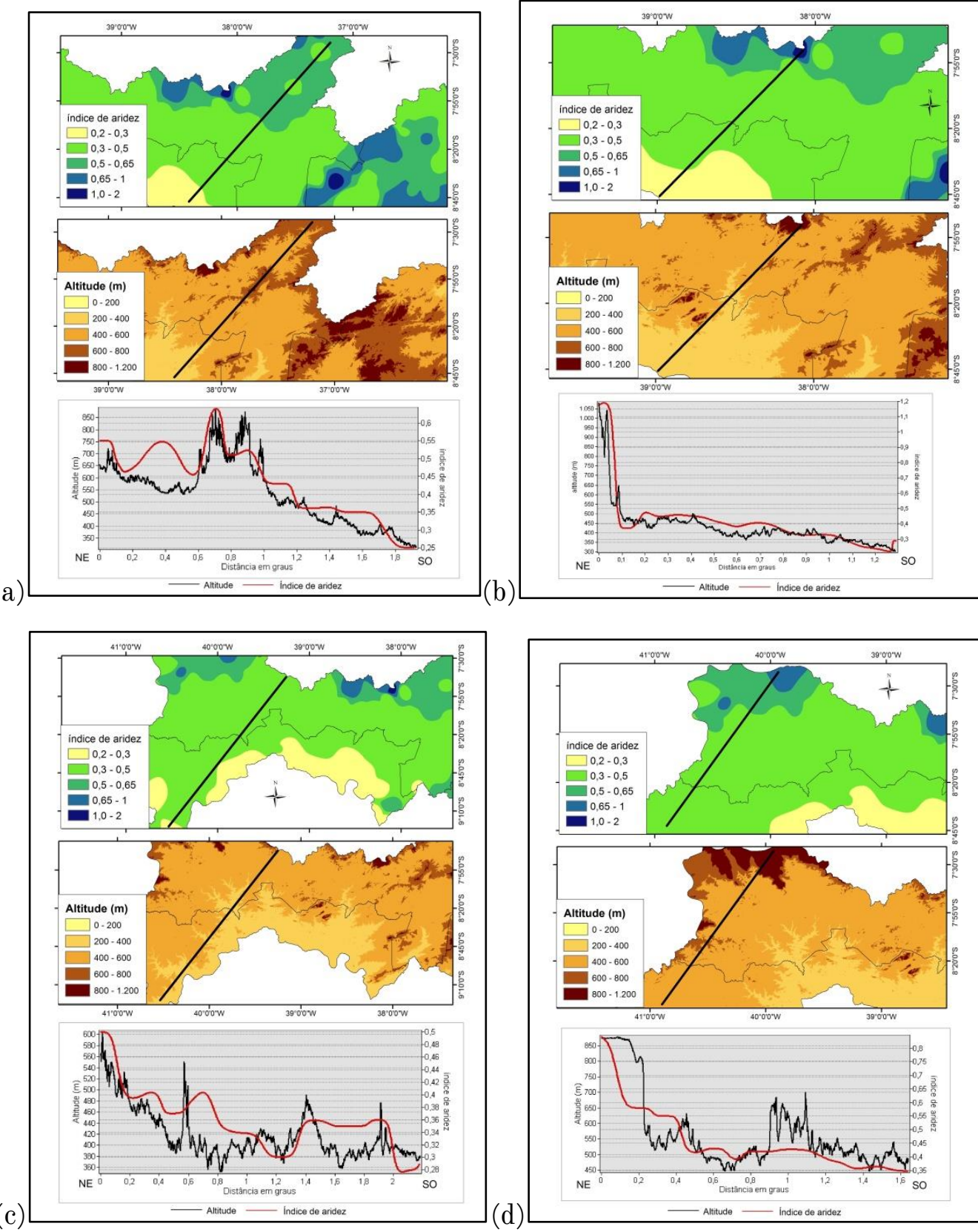

Figura 5: perfis 6 (a), 7 (b), 8 (c) e 9 (d) com dados relativos a altitude e ao índice de aridez (1960-2016). Fonte: organizado pelos autores.

Os gráficos e mapas apresentados sobre os perfis permitem averiguar que são observados padrões espaciais de IA relacionados com o arranjo do relevo. Esse fato fica mais evidente, na escala de análise, a partir das escarpas do Planalto da Borborema. Observou-se que as áreas semiáridas dos perfis localizados no Agreste coincidem com depressões existentes no interior do Planalto. A gênese dessas áreas secas é explica pelo acoplamento da subsidência do ar das células de circulação HadleyWalker com a subsidência de sotavento, como descrito por Reboita et al. (2016). Por outro lado, as 
áreas mais úmidas no Agreste e Sertão estão na maioria das vezes associados a escarpas a barlavento ou topografias elevadas $(>600 \mathrm{~m})$ que favorecem a ocorrência de chuvas orográficas

\section{Modelo linear de regressão do IA pela altitude}

A análise dos gráficos de dispersão entre a altitude e o IA demostrou distinções dos controles topográficos sobre o clima entre os perfis, como pode ser observado na Figura 6 . Nos perfis 1 e 2 localizados na Zona da Mata de Pernambuco observou-se uma correlação negativa entre as variáveis representadas no gráfico, indicando que o aumento das cotas topográficas é associado a uma diminuição nos valores do IA. Entretanto, o grau de previsibilidade linear do IA em função do relevo é fraco nos perfis $1\left(R^{2}=0,53\right)$ e $2\left(R^{2}=0,32\right)$.

Para os perfis 3, 4 e 5, situados na mesorregião do Agreste, os modelos de regressão linear mostraram previsibilidades baixas, com valores de $\mathrm{R}^{2}$ de 0,$45 ; 0,29$ e 0,57 para os respectivos perfis. De modo antagônico aos transectos localizados na Zona da Mata os gráficos de dispersão para os perfis do Agreste mostraram uma fraca relação positiva entre o IA e a altitude. Nas mesorregiões do Sertão e do São Francisco o modelo de previsibilidade linear indicou fortes relações nos perfis $6\left(\mathrm{R}^{2}=0,82\right)$ e 7 $\left(R^{2}=0,89\right)$, relação moderada no perfil $9\left(R^{2}=0,69\right)$ e fraca no perfil $8\left(R^{2}=0,48\right)$.
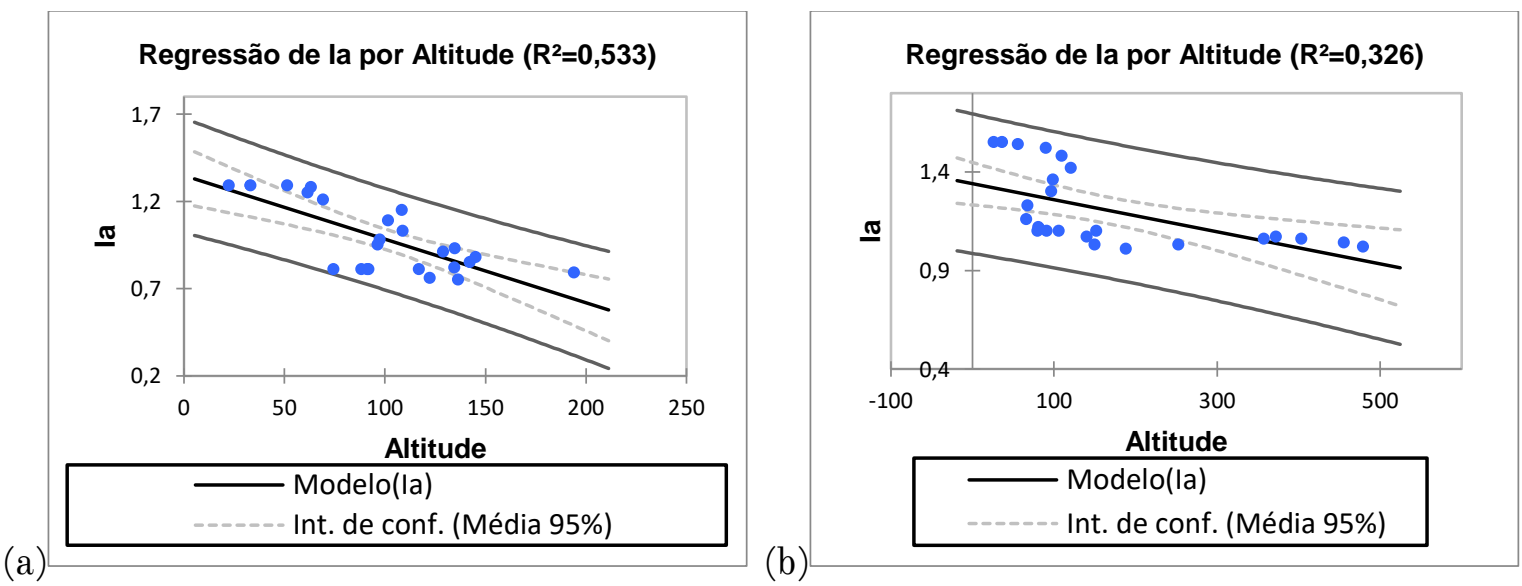
(c)

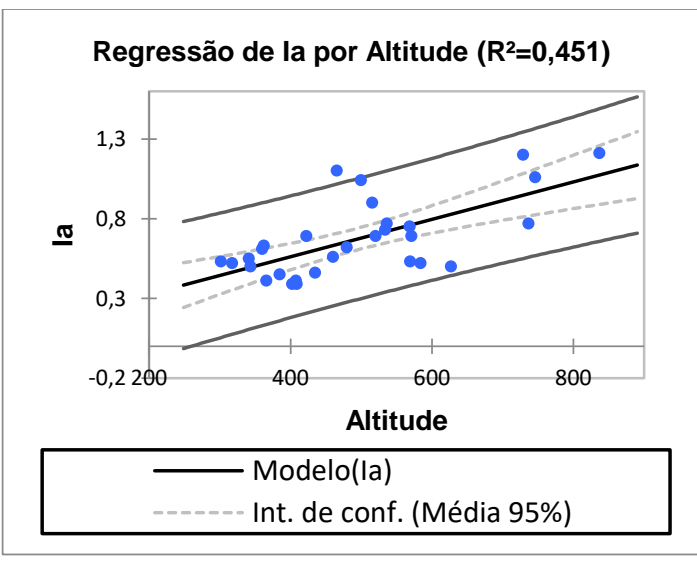

(e)

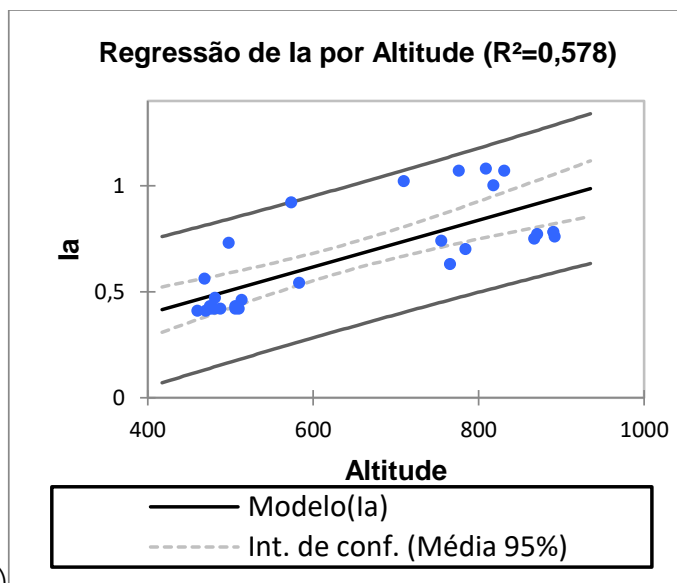

Regressão de la por Altitude $\left(R^{2}=0,895\right)$

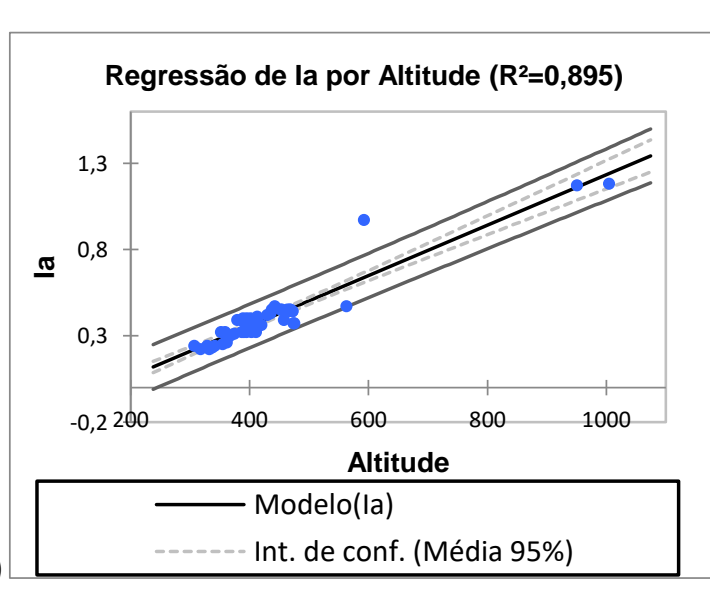

(d)

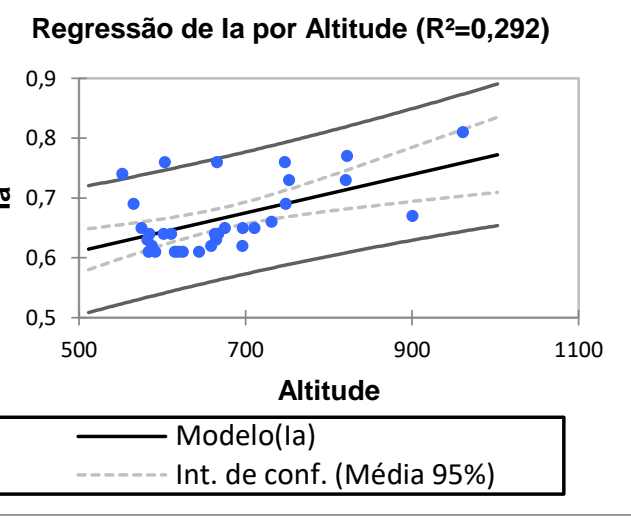

Regressão de la por Altitude $\left(R^{2}=0,823\right)$

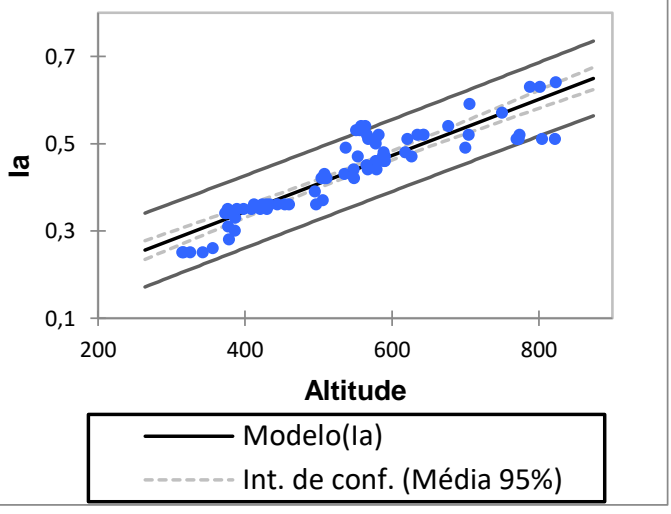

(f)

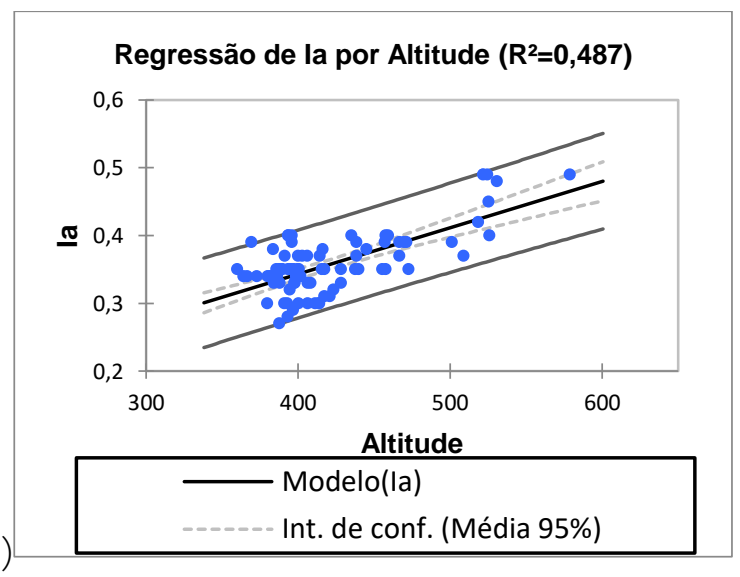

(h)

\section{(g)}

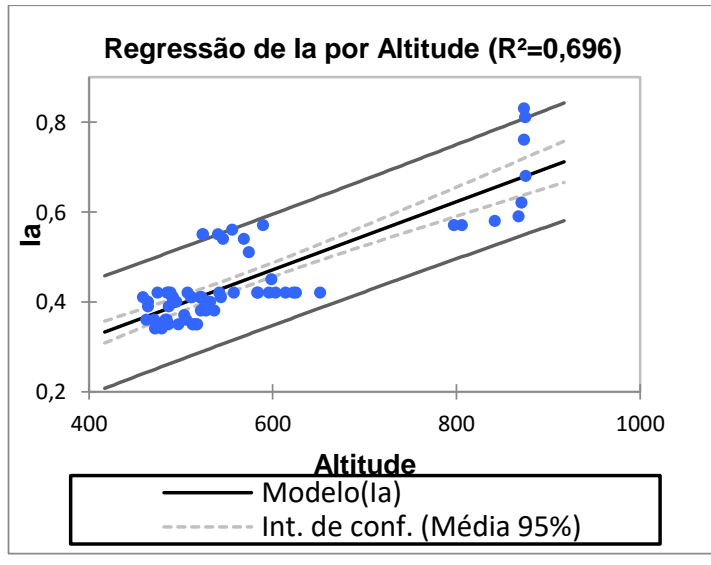


Figura 6. gráficos de dispersão da altitude por IA para os perfis 1(a), 2(b), 3(c), 4(d), 5(e), 6(f), 7(g), 8(h), 9(i). Fonte: organizado pelos autores.

Através da análise dos gráficos de dispersão, averiguou-se que nos perfis localizados na Zona da Mata e na Região Metropolitana do Recife o modelo não possui boa previsibilidade do IA em função da altitude. Esse fato pode ser interpretado considerando que o aumento do grau de aridez em direção ao interior, até as escarpas do Planalto da Borborema, possui maiores relações com o enfraquecimento dos sistemas atmosféricos produtores de chuvas nas proximidades do litoral (como as brisas e os DOLs) à medida que se distanciam da costa. A perda gradativa de umidade na base da massa de ar que avança sobre o continente, e a baixa camada de inversão dos alísios também são fatores que contribuem para esse padrão espacial do IA na Zona da Mata.

Em áreas de relevo complexo como no Agreste de Pernambuco a relação entre a topografia e o IA não ocorre de maneira linear, em concordância com os resultados obtidos por Souza et al. (2015). Hipoteticamente, maciços ou cristas de serras mais elevados estariam submetidos a um regime climático mais úmido, e as áreas mais baixas a regimes climáticos mais secos. Entretanto, os perfis demonstraram que serras localizadas a sotavento de outras proeminências do relevo podem não possuir o grau de aridez previsto pelo modelo linear em função da altitude. Nesse caso áreas com altitudes iguais ou superiores a 600 m podem estar submetidas a um regime climático semiárido ou subúmido seco e, Do mesmo modo, áreas de baixa altitude podem apresentar climas mais úmidos em virtude de sua localização, a barlavento, na escarpa do Planalto da Borborema.

A presença de áreas elevadas sob influência de climas semiáridos pode estar relacionada à elevação no nível de convecção livre (NCL) na atmosfera. A baixa umidade relativa do ar, intensificada por movimentos atmosféricos subsidentes, a sotavento de proeminências orográficas antecedentes, pode explicar, assim como propôs Geng et al. (2017), a elevação do NCL nestes locais. Desse modo, a existência de climas mais úmidos em serras interiores do Planalto da Borborema exige uma maior altitude do que em escarpas orientadas a barlavento em relação aos ventos úmidos oceânicos. Por outro lado, áreas de relevo aplainados, a exemplo da Depressão Sertaneja com elevações localizadas, observadas nos perfis 6 e 7, apresentam uma maior previsibilidade linear. Nesses perfis os controles 
exercidos pelo relevo sobre o IA são mais evidentes em virtude de uma menor complexidade topográfica do relevo.

\section{Paisagens fitoclimáticas associadas aos perfis topográficos}

Foram apresentados como produtos finais do presente estudo perfis topográficos esquemáticos de paisagens fitoclimáticas. Para os perfis 1 e 2 (apresentados na Figura 7), inseridos na Zona da Mata e Região Metropolitana do Recife, os climas úmidos e subúmidos foram associados a florestas ombrófilas e florestas estacionais, localizadas entre o litoral e as escarpas orientais do Planalto da Borborema. No perfil 1 a paisagem fitoclimática com clima úmido $(\mathrm{U})$ e floresta ombrófila (Fo) predomina até o quilômetro 40, e partir de então ocorre clima subúmido úmido (S4) com floresta estacional semidecidual (Fe) até o quilômetro 55. A partir de então, e até o final do transecto, predomina uma zona de clima subúmido com contato entre floresta ombrófila e floresta estacional, como resposta a uma elevação topográfica de $150 \mathrm{~m}$. No perfil 2, localizado no setor meridional da Zona da Mata, o clima úmido ocorre até os piemontes do Planalto da Borborema com composição florística pretérita de florestas ombrófilas até o quilômetro 52. Nas escarpas do planalto observa-se a existência de florestas estacionais semideciduais.

(a)

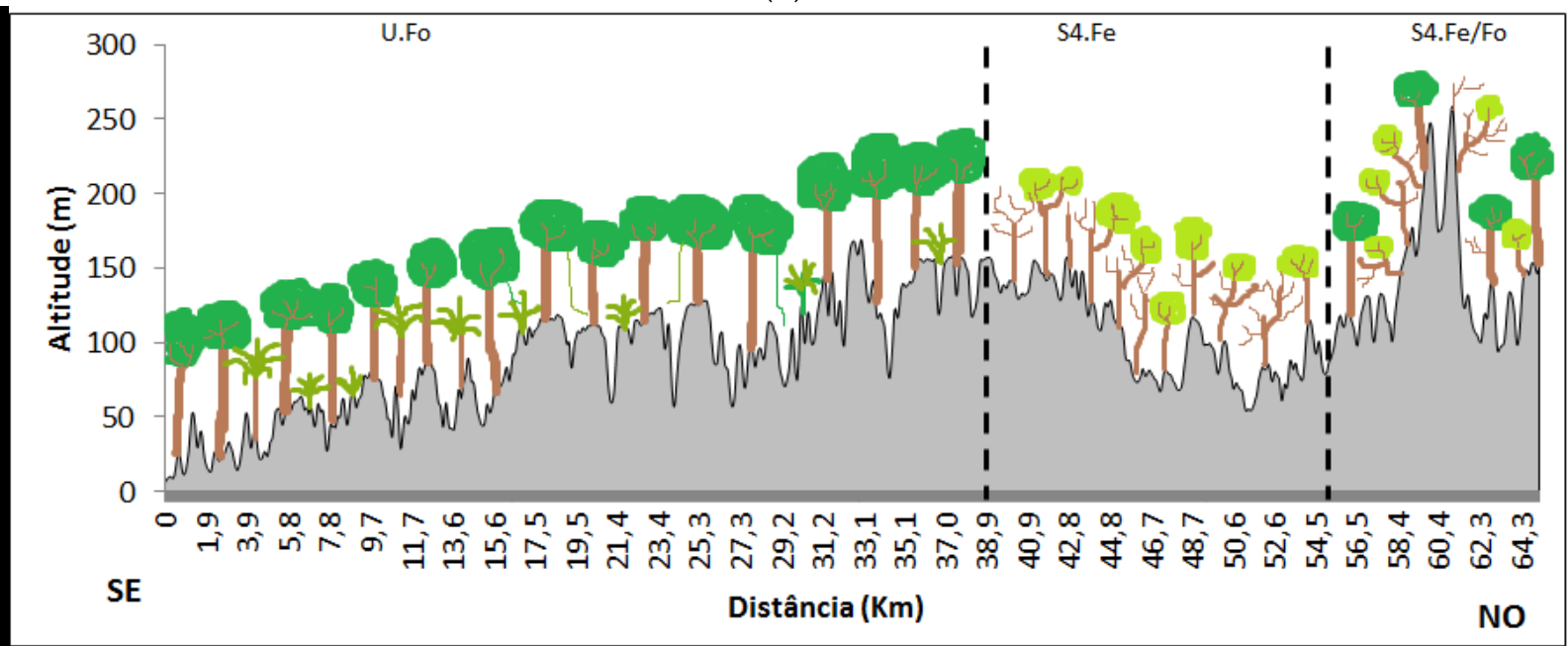

(b) 


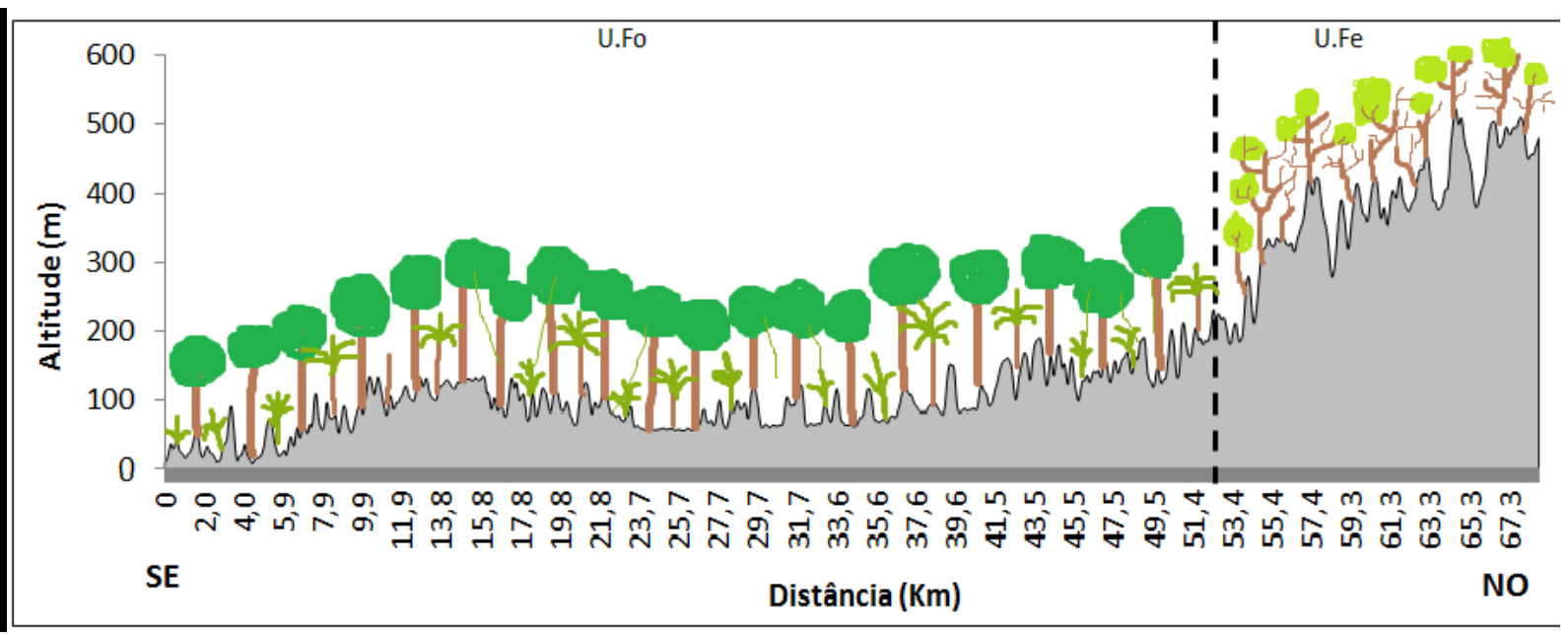

Figura 7. perfis paisagísticos 1 (a) e 2 (b), localizados nas mesorregiões da Região Metropolitana do Recife e da Zona da Mata do estado de Pernambuco. Fonte: organizado pelos autores

As paisagens apresentadas nos perfis do Agreste demonstram, de modo geral, uma correspondência entre áreas de barlavento e sotavento com os padrões fitogeográficos esperados para tais áreas. Nos perfis 3,4 e 5 predominam paisagens de caatingas em regimes climáticos subúmidos. No perfil 3, apresentado na Figura 8(a), a paisagem semiárida ou subúmida seca com caatinga, a sotavento, está restrita entre os quilômetros 23 e 57 e entre os quilômetros do 69 e 80 do transecto, e a paisagem úmida com floresta ombrófila encontra-se em quatro pequenos trechos entre 2 e $5 \mathrm{Km}$ de extensão, com influência orográfica evidente. 0 transecto 4, apresentado na Figura 7(b), apresenta-se como uma rampa crescente, de inclinação suave entre 600 e 700 m de altitude em sua área central, com clima subúmido seco e vegetação de caatinga. As extremidades desse perfil apresentam altitudes mais elevadas e clima subúmido com transição entre caatinga e floresta estacional. Nas paisagens do perfil 5, apresentado na Figura 8 (c), também há uma clara influência topográfica de seus padrões espaciais, pois ocorrem climas úmidos e subúmidos úmidos nas áreas mais elevadas do relevo e climas subúmidos secos e semiáridos nas depressões e escarpas de serra. A distribuição fitogeográfica do perfil permite associar os climas subúmidos úmidos às zonas de contato entre florestas semideciduais e a caatinga e relacionar os climas subúmidos secos e semiáridos às áreas de caatinga. 


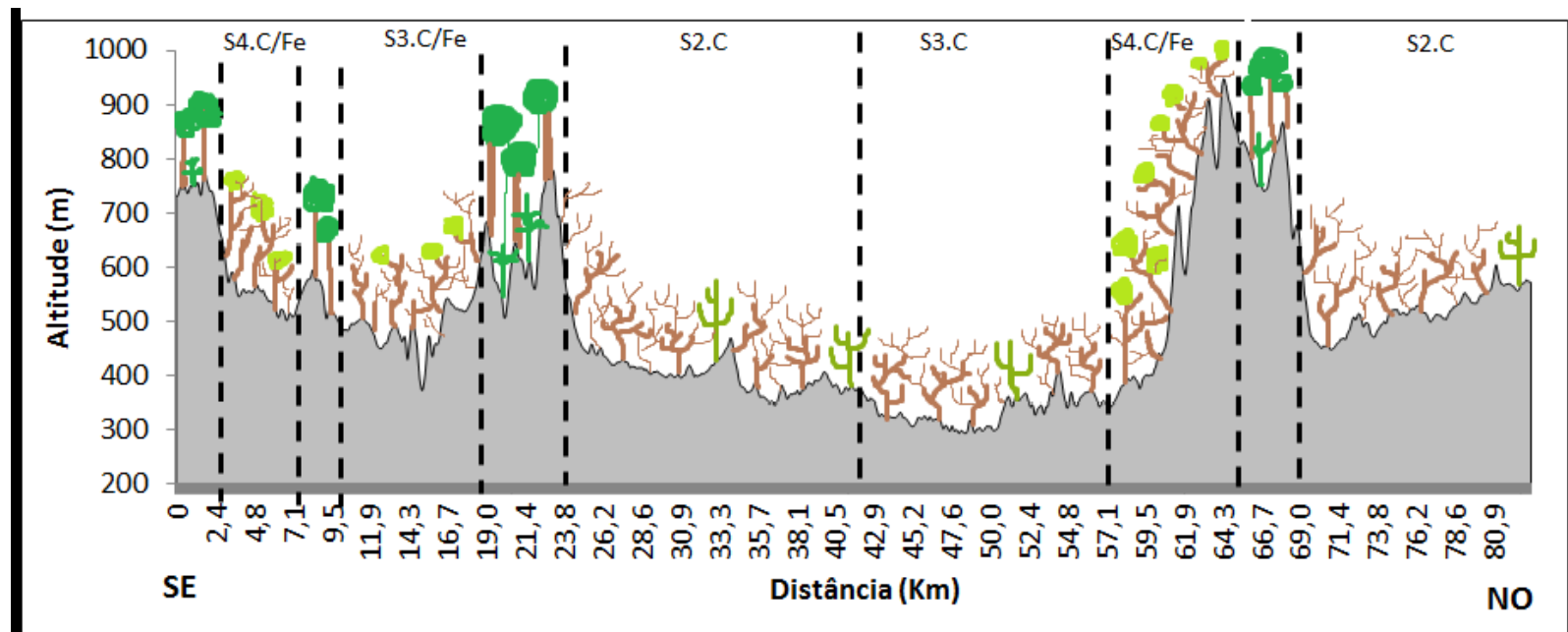

(b)

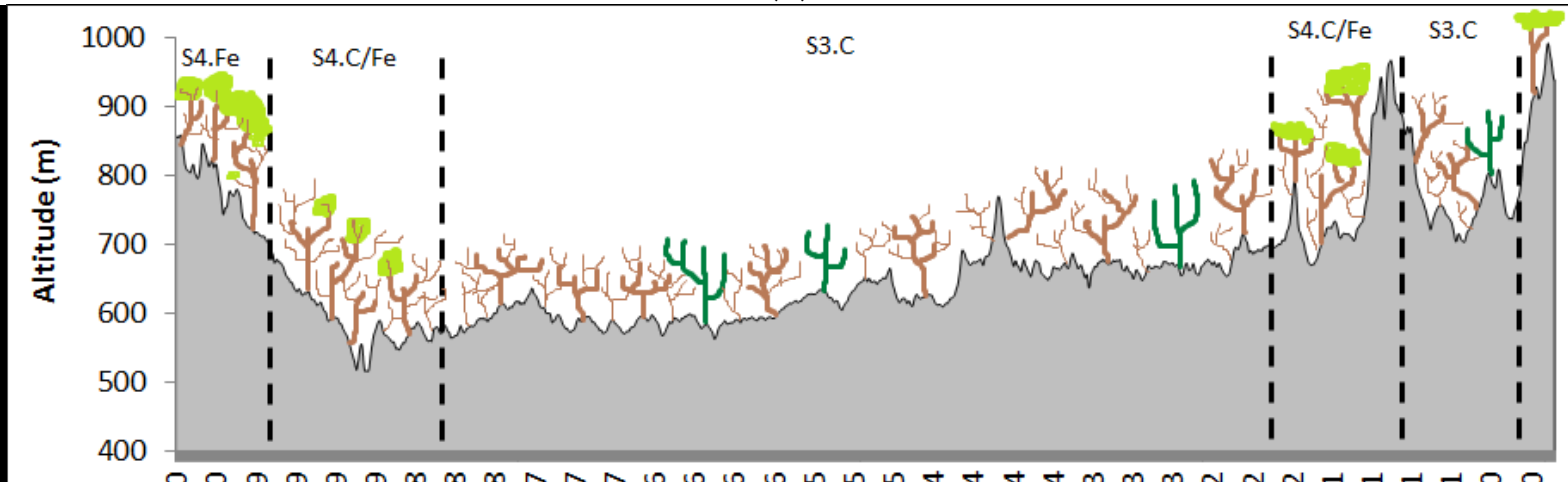

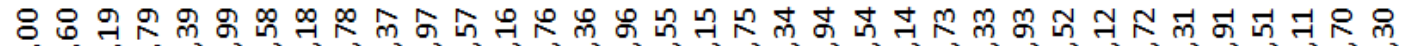

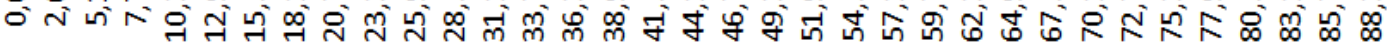

SE Distância (Km)

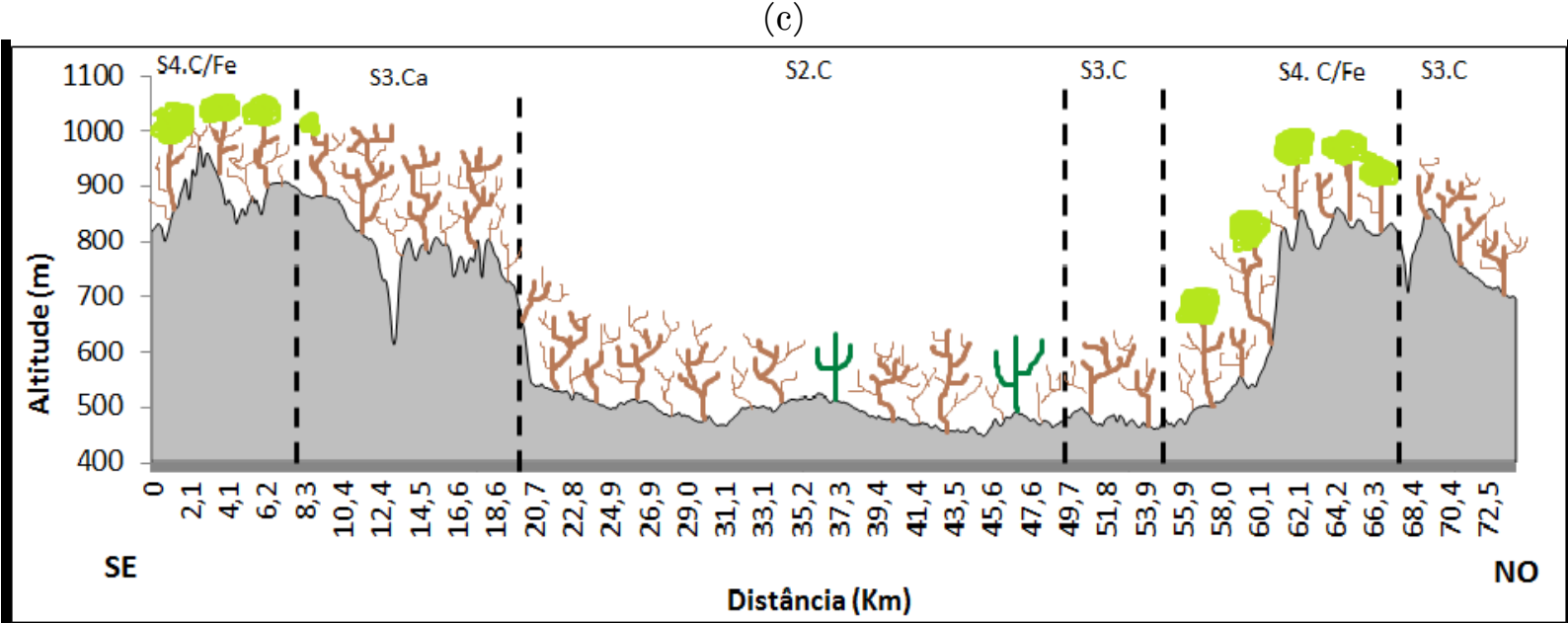

Figura 8. perfis paisagísticos 3 (a), 4 (b)e 5(c), localizados na mesorregião do Agreste do estado de Pernambuco. Fonte: organizado pelos autores.

Nos perfis do Sertão, apresentados na Figura 9, a influência topográfica sobre a disposição espacial das paisagens aparece com maior nitidez. Neste ambiente, o clima semiárido com caatinga predomina sobre as amplas regiões aplainadas a partir da cota de 600 m. O clima semiárido severo está relacionado às depressões do Rio São Francisco, a partir de cota de 400 m. Já os climas subúmidos 
com caatinga arborizada ou floresta estacional e o clima úmido com floresta ombrófila foram observados sobre as encostas de relevo e superfícies de cimeira a partir da cota altimétrica de $600 \mathrm{~m}$.

(a)

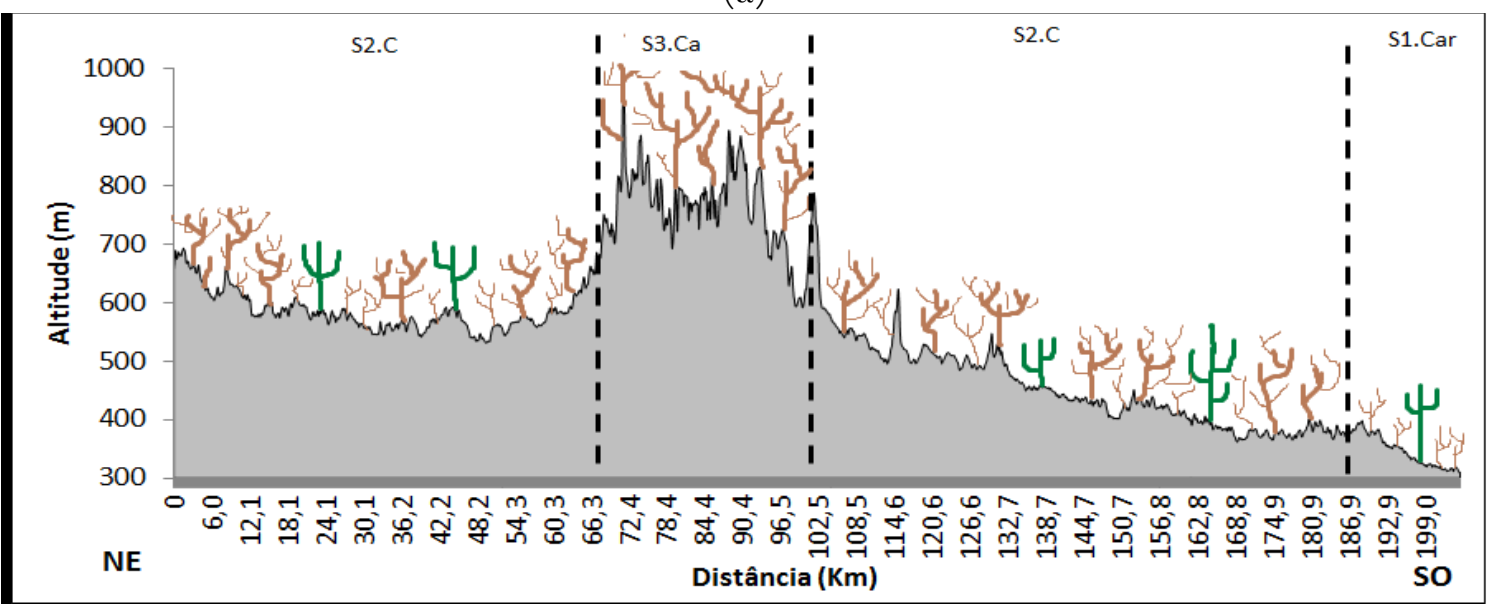

(b)

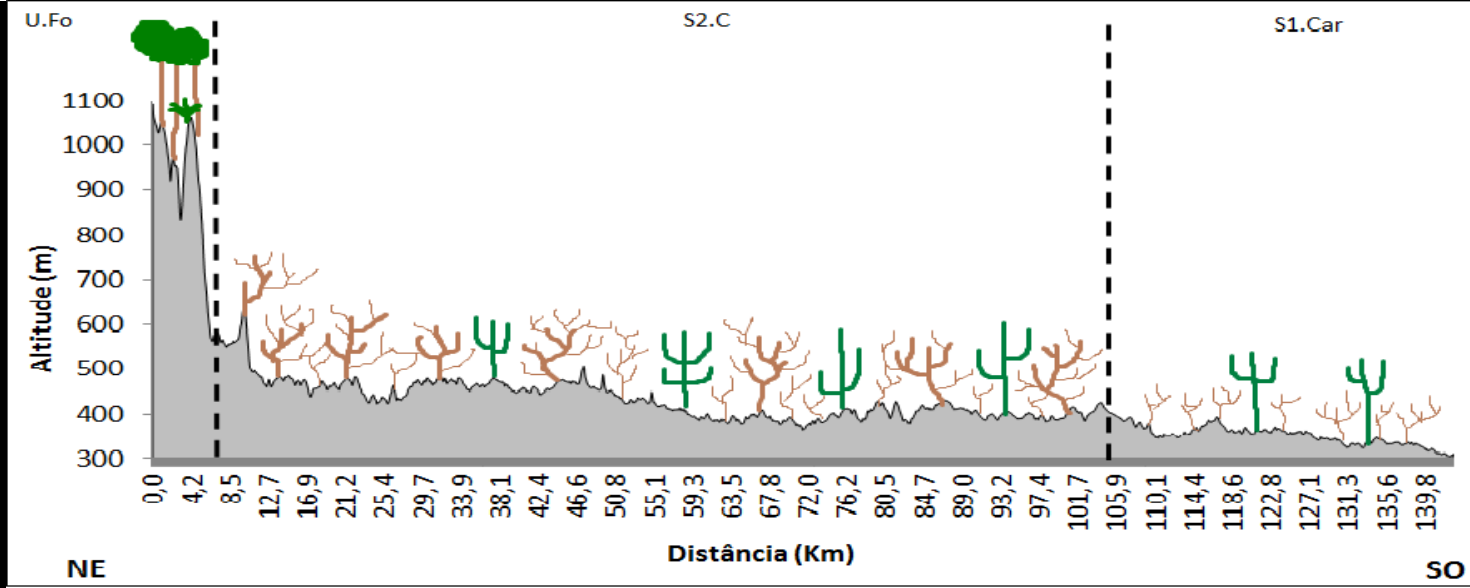

(c)

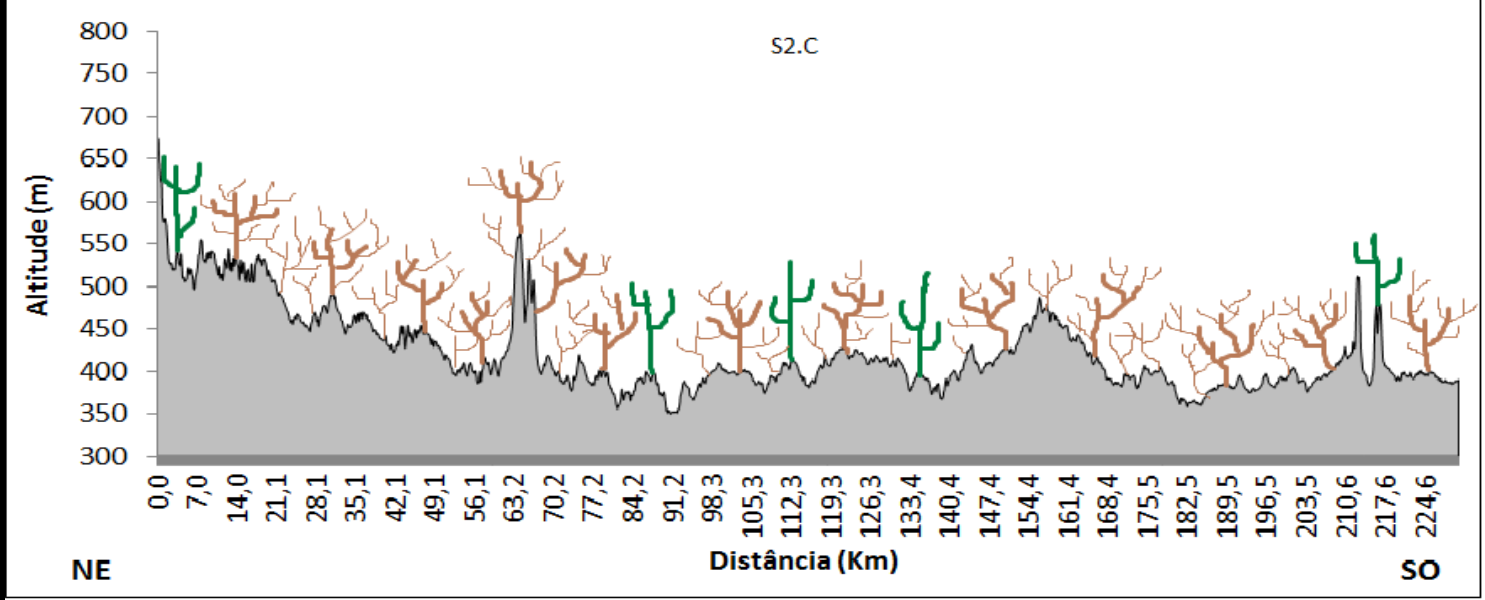

(d) 


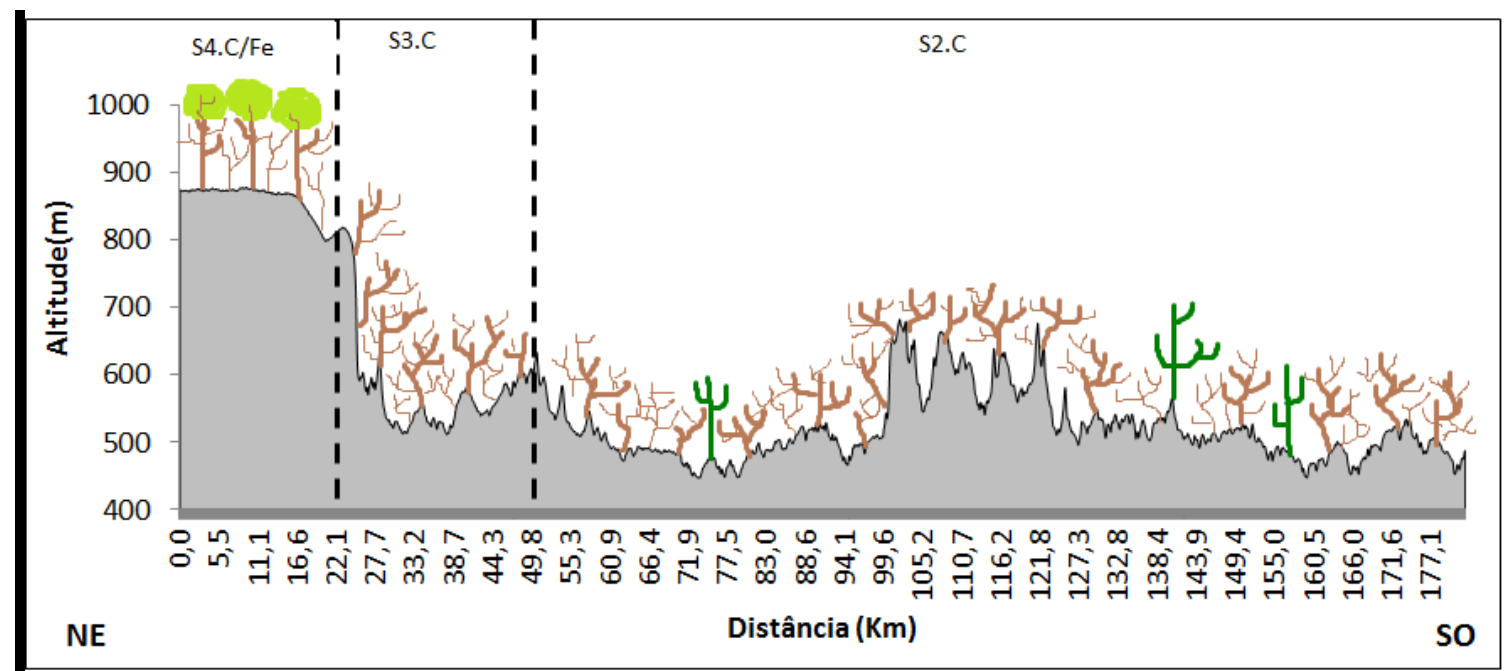

Figura 9. perfis paisagísticos 6 (a), 7 (b), 8 (c) e 9 (d), localizados nas mesorregiões do Sertão e do São Francisco do estado de Pernambuco. Fonte: organizado pelos autores.

Os padrões espaciais apresentados nos perfis paisagísticos corroboram a influência do relevo sobre a dinâmica climática e ambiental do estado de Pernambuco. Ficou constatado que a interação dos elementos atmosféricos com o relevo ocorre de modo distinto nas mesorregiões do estado, culminando em uma expressiva variedade de paisagens úmidas, subúmidas e semiáridas.

\section{Considerações finais}

A partir das análises e discussões apresentadas foi possível verificar que a topografia se relaciona com o índice de Aridez (IA) de maneira diferenciada de acordo com os sistemas atmosféricos atuantes e com o arranjo espacial das formas de relevo.

Os perfis localizados na Região Metropolitana do Recife e na Zona da Mata demonstram uma diminuição da umidade à medida que a distância em relação ao oceano aumenta. Esse fato pode ser explicado pelos sistemas atmosféricos atuantes sobre essas áreas, pois os Distúrbios Ondulatórios de Leste (DOLs) e o efeito das brisas tendem a perder energia em direção ao interior do continente. Para a escala de análise apresentada, esses perfis demonstraram uma relação inversa entre altitude e IA, apesar não existir uma boa previsibilidade linear do IA em função da altitude. Ademais os perfis 1 e 2 encontram-se sobre domínio paisagístico dos climas úmidos e subúmidos úmidos com florestas ombrófilas e estacionais. 
Os transectos da mesorregião do Agreste, a partir da cota altimétrica de $600 \mathrm{~m}$ na escarpa oriental do Planalto da Borborema, sugerem uma relação positiva entre a altitude e o IA. Todavia, a complexidade do relevo desses perfis não permite a existência de uma boa previsibilidade linear do IA, assim como na Zona da Mata. A paisagem predominante é caracterizada pela associação entre climas subúmidos com caatingas sobre pediplanos ou serras do Planalto da Borborema. Nessa mesorregião, a ocorrência do clima semiárido com caatingas está relacionada ao acoplamento da subsidência atmosférca gerada pelas células de Hadley e Walker com os movimentos descendentes das correntes de ar a sotavento das serras elevadas do planalto. De modo análogo, os climas úmidos e subúmidos úmidos estão preferencialmente localizados em escarpas a barlavento ou em cimeiras.

Nas mesorregiões do Sertão e São Francisco, os perfis mostraram uma relação positiva do relevo com o IA, ainda mais evidente do que nos perfis do Agreste. Para essas mesorregiões do estado de Pernambuco o modelo de regressão linear previu com maior eficiência o IA em função da altitude. Esse fato pode ser associado a uma menor complexidade topográfica dessas mesorregiões quando comparada ao Agreste. Para os perfis dessas áreas as combinações paisagísticas dominantes são representadas por clima semiárido com caatingas entre as cotas altimétricas de 500 a $400 \mathrm{~m}$. Os climas subúmidos úmidos e úmidos com floresta estacional ou até floresta ombrófila estão restritos as áreas elevadas de maciços do Planalto da Borborema, Chapada do Araripe ou cristas de serras, preferencialmente a partir da cota de $600 \mathrm{~m}$ nas escarpas do relevo.

Portanto, os resultados permitem afirmar que foi identificada uma importante relação do relevo com a distribuição espacial das paisagens no estado de Pernambuco.

\section{AGRADECIMENTOS}

Os autores do presente artigo agradecem o apoio financeiro e logístico da Coordenação de Aperfeiçoamento de Pessoal de Nível Superior (CAPES), da Fundação de Amparo à Ciência e Tecnologia do Estado de Pernambuco (FACEPE) (SIN-0686-5.01/17 e BPV-007-5.01/17) e do Instituto Agronômico de Pernambuco. 


\section{REFERÊNCIAS}

Brasil. Instituto Nacional de Pesquisas Espaciais (INPE). Topodata: banco de dados geomorfométricos do Brasil. Variáveis geomorfométricas locais. São José dos Campos, 2008.

GENG, H.; PAN, B.; HUANG, B.;CAO, B.; GAO, H. The spatial of precipitation and topography in the Qilian Shan Mountains, northeastern Tibetan Plateau. Geomorphology. V.297, p.43-54, 2017.

JOHnsOn, F.; HUTCHINSON, C.; BEESLEY, C.; GREEN, J. Journal of Hydrology. V.533, p.439-451, 2015.

MATALLO JUNIOR, H. Desertificação. 2ed. Brasília. CNPq/ IBCIT/ UNESCO, 2003.

MEDINA, S., HOUZE, R., KUMAR, A., NIYOGI, D.. Summer monsoon convection in the Himalayan region: terrain and land cover effects. Quarterly Journal of the Royal Meteorological Society v.136, p.593-616, 2010.

MILANESI, M.A.; GALVANI, E. Efeito orográfico na Ilha de São Sebastião, Ilhabela-SP. Revista Brasileira de Climatologia. n.9, p.69-79, 2011.

MOLION, L.C.B.; BERNARDO, S.O. Uma revisão da dinâmica das chuvas no Nordeste Brasileiro. Revista Brasileira de Meteorologia, v.17, n.1, p. 1-10, 2002.

NOGUEIRA DE SOUZA, M., OLIVEIRA, J. G. B., LINS, R. C.; JATOBÁ, L. Condições geo-ambientais do semiárido Brasileiro. CI \& Trópicos, Recife, V.20, n. 1, p. 173-198. 1992.

PEREIRA, T. Influência do relevo na precipitação das regiões hidrográficas do litoral norte de alagoas. GEOUSP-espaço e tempo, n.33, p.239-253, 2013.

REBOITA, M.S.; RODRIGUES, M.; ARMANDO, R.; FREITAS, C.; MARTINS, D.; MiLlER, G. Causas da semiaridez do Sertão Nordestino. Revista Brasileira de Climatologia. n.12, v.19, p.254-277, 2016.

SILER, N.; ROE, G.; DURAN, D. On the Dynamical Causes of Variability in the Rain Shadow Effect: A Case Study of Washington Cascades. Journal of Hydrometeorology, v.14, p.122-138, 2013.

SILVA, A.S. A. Ferramentas para modelagem e interpretação de dados ambientais em escala regional. 2015.104 p. Tese (Doutorado em Biometria e Estatística Aplicada) - Universidade Federal Rural de Pernambuco, Recife-PE.

SILVA, V ; SOUSA, F ; CAVALCANTI, E.P. ; SOUZA, E ; DASILVA, B. B. Teleconnections between sea-surface temperature anomalies and air temperature in northeast Brazil. Journal of Atmospheric and Solar-Terrestrial Physics, Canada, v. 68, n. 68, p. 781-792, 2006

SILVA, A.S. A. Ferramentas para modelagem e interpretação de dados ambientais em escala regional. 2015.104 p. Tese (Doutorado em Biometria e Estatística Aplicada) - Universidade Federal Rural de Pernambuco, Recife-PE.

SMITH, Ronald. The influence of mountains on the atmosphere. New Haven, Connecticut: Ed. Advances in Geophysics, p.87-230, 1979 .

SOUZA, J.O.P.; ALMEIDA, J.D.M.; CORREA, A.C.B. Caracterização e espacialização em bacia hidrográfica com relevo complexo: Sertão Central pernambucano -bacia do Riacho do Saco. Revista de Geografia (UFPE), v.32, n.2, p.106-126, 2015 .

THORNTHWAITE, C. W., MATHER, J. R. The water balance. Drexel Institute of Technology, New Jersey, 1955. 
OLIVEIRA, M.R.P.; GALVANI, E. Avaliação do efeito orográfico no perfil longitudinal Paraty (RJ) e Campos do Jordão (SP). Entre Lugar (UFGD). V.6, n.11, p.133-151, 2015.

ORGANIZAÇÃO DAS NAÇÕES UNIDAS. Agenda 21. Conferência das Nações Unidas sobre meio ambiente e desenvolvimento. Rio de Janeiro, 1992. São Paulo, Secretaria do Meio Ambiente, 1997. 